\section{Multivariate Analysis and Selection Indices to Identify Superior Quince Cultivars for Cultivation in the Tropics}

\author{
Givago Coutinho and Rafael Pio \\ Departamento de Agricultura, Universidade Federal de Lavras, Lavras, MG, \\ 37200-000, Brazil
}

Filipe Bittencourt Machado de Souza
Centro Universitário Tocantinense Presidente Antônio Carlos (UNITPAC),
Araguaína, Tocantins, Brazil, 77816-540

Daniela da Hora Farias ${ }^{1}$ and Adriano Teodoro Bruzi

Departamento de Agricultura, Universidade Federal de Lavras, Lavras, $M G$, 37200-000, Brazil

\section{Paulo Henrique Sales Guimarães \\ Departamento de Estatística, Universidade Federal de Lavras/UFLA, Lavras - MG, Brazil, 37200-000}

Additional index words. Cydonia oblonga, genetic diversity, rank summation index, Z-index

Abstract. Among the fruit species cultivated in subtropical climates, quince has productive cultivars with high horticultural potential. The objectives of this study were to evaluate the genetic divergence among quince cultivars through multivariate procedures and to identify cultivars for cultivation in the tropics through selection indices. Twentyseven productive quince cultivars were grown in a location with a high-altitude tropical climate. The number of fruit, estimated yield, flowering period, number of buds, number of shoots, number of brindles per shoot, shoot length, average fruit weight, fruit length, and fruit diameter were measured. A multivariate principal component analysis (PCA) associated with the unweighted pair group method with arithmetic means (UPGMA) based on Gower distance and Pearson correlation coefficients was used to evaluate genetic divergence. Superior cultivars were defined by the selection index based on the rank summation index and the $Z$-index. UPGMA grouping indicated there was genetic variability among cultivars and showed that groups that were more dissimilar [e.g., the cultivars Bereckzy and Champion (distance $=0.69$ )] had the potential to be used in future stages of quince selection. The estimated yield, shoot length, fruit weight and diameter, and flowering period contributed to the maximum variability among quince cultivars. The selection indices identified cvs. Bereckzy, Alaranjado, and Alongado (30, 68, and 73 rank summation index, respectively) as superior, simultaneously considering the evaluated traits with greater potential for cultivation in the tropics.

The quince tree (Cydonia oblonga Miller) belongs to the genus Cydonia and originates from temperate regions (Rigitano, 1957). The world production of quinces is $596,532 \mathrm{t}$; Turkey leads world production with 135,500 t, followed by China, Iran, Argentina, Azerbaijan, and Spain (FAO, 2017).

Horticulture plants - in particular, minor ones, including quince-have been recognized for their human health benefits. They

Received for publication 25 Mar. 2019. Accepted for publication 21 May 2019.

This study was financed in part by the coordenação de Aperfeiçoamento de Pessoal de Nível Superior Brasil (CAPES) - Finance Code 001 and Conselho Nacional de Desenvolvimento Científico e Tecnológico $(\mathrm{CNPq})$, as well as the Universidade Federal de Lavras (UFLA) for providing the structure for carrying out the study.

${ }^{1}$ Corresponding author. E-mail: dhorafarias@ gmail.com. quince production in subtropical regions, only the Portugal cultivar is used in canneries (Seifert et al., 2009).

There are few studies on the agronomic performance of quince cultivars cultivated in the tropics, especially in humid subtropical climates, which hiders the selection of cultivars with superior agronomic characteristics and the use of this fruit in regions with a mild climate. In addition, regarding cultivated crops in the tropics, it is possible to harvest fruit trees that originated from areas with temperate climates during low-supply seasons (Barbosa et al., 2010; Chagas et al., 2012). This phenomenon occurs because fruit can be harvested earlier in warmer regions than in colder regions (Souza et al., 2013). This early maturity is a result of the warmer winter, which allows pruning and sprouting to occur in winter because there is no risk of late frost (Bettiol Neto et al., 2011).

Previous studies showed that quince cultivars have high genetic variability (Kafkas et al., 2015; Orhan et al., 2014); hence, the characterization of productive cultivars with high horticultural potential for cultivation in the tropics is crucial to maintain productivity (Manica-Berto et al., 2013). In addition, the selection of cultivars should not be based on a single factor, because cultivars with economic potential have multiple traits of agronomic interest, such as traits related to productive performance, adaptability, and stability in production (Bertini et al., 2010).

To advance the selection of cultivars, tools based on multivariate analyses have become essential in developing studies for plant breeding programs. According to Cruz et al. (2004), comparing results from several multivariate analysis techniques provides a more accurate interpretation of the differences among cultivars, affording a more accurate interpretation of results with a low demand for resources and work in breeding programs.

Another tool widely used in cultivar selection is the multiple-trait selection index, which allows more productive and adapted cultivars to be obtained through combining several attributes. The rank summation index proposed by Mulamba and Mock (1978), as a nonparametric index, has the advantage of not requiring economic weights or the estimated parameters besides averages. In general, the rank summation index is based on genotype ranking in relation to the desired trait and, subsequently, the sum of the ranks of several traits simultaneously (Cruz et al., 2004; Teixeira et al., 2012). Moreover, the selection index based on the sum of standardized variables, or Z-index, is an alternative to other indices. It does not require estimates of genetic and phenotypic covariance and it allows the traits that have favorable effects on the cultivar to be visualized (França et al., 2016).

Thus, the aim of this study was to evaluate the genetic divergence among quince cultivars through multivariate procedures and to identify superior cultivars for cultivation in the tropics through selection indices. 


\section{Material and Methods}

The experiment was conducted at an experimental orchard south of Minas Gerais State, the municipality of Lavras, Brazil. The Köppen climate classification of the study region is Cwa (lat. $21^{\circ} 14^{\prime} \mathrm{S}$, long. $45^{\circ} 00^{\prime} \mathrm{W}$; average altitude, $918 \mathrm{~m}$ ), which indicates a high-altitude tropical climate with cold and dry winters and warm and moist summers (Alvares et al., 2013).

Plants were propagated by grafting using Chaenomeles sinensis 'Japonês' as the root- stock. Twenty-seven quince cultivars belonging to the species Cydonia oblonga, were studied: Alaranjado, Alongado, Apple, Bereckzy, Champion, Cheldow, Constantinopla, CTS, Dangers, De Patras, De Vranja, Dulot, Fuller, Kiakami, Lajeado, Meech Prolific, Meliforme, Mendoza Inta-37, Pera, Pineapple, Portugal, Provence, Radaelli, Reas Mamouth, Smyrna, Van Deman, and Zuquerineta.

The plantation was established in 2010, and the experimental plots consisted of six

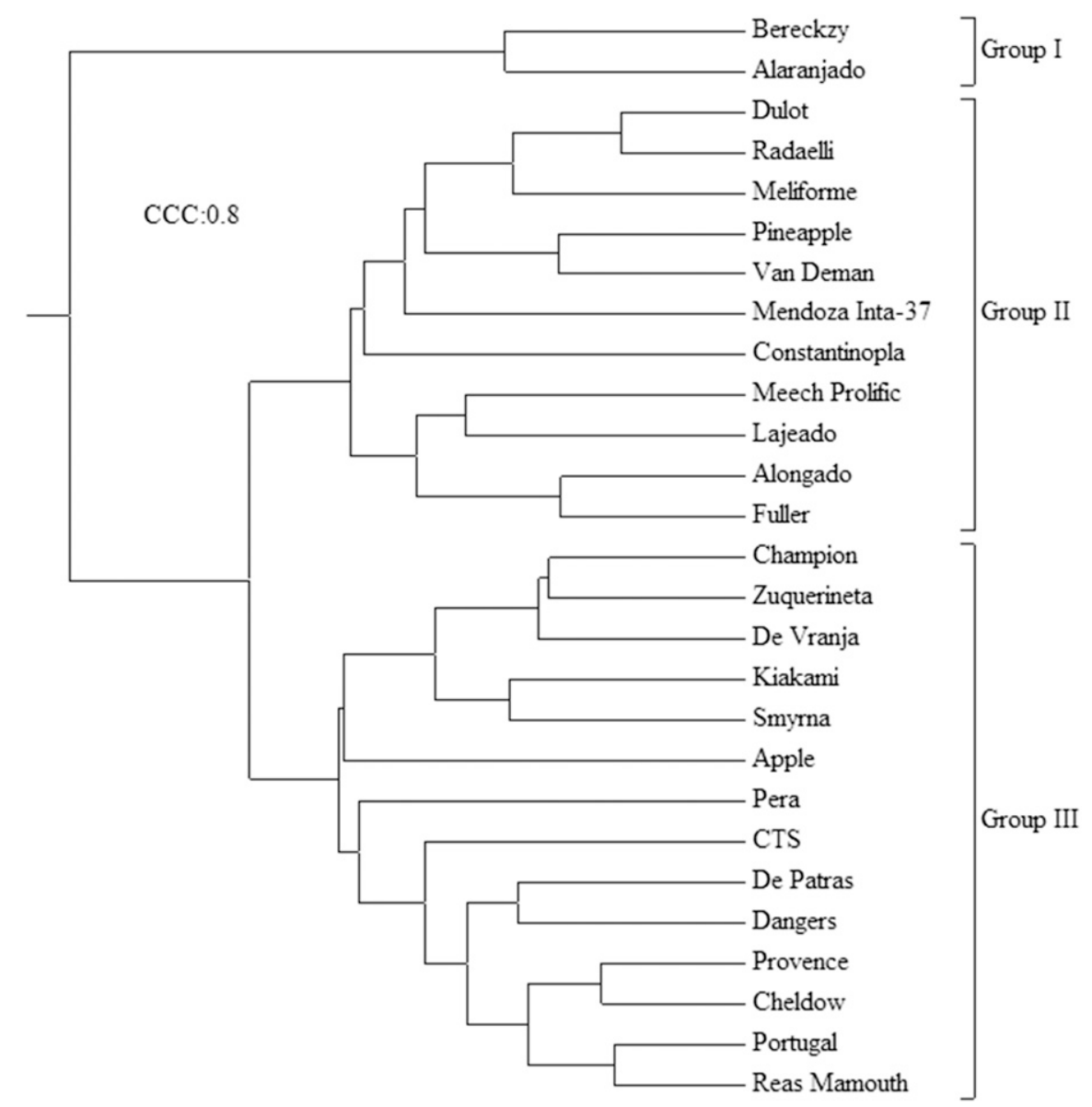

plants per cultivar, with $2.5-\mathrm{m}$ spacing between plants and $4.0-\mathrm{m}$ spacing between rows. Pruning was completed at beginning of June throughout the three productive cycles evaluated (2013-16). In pruning, excess branches were removed from the inner portion of the canopy. The branches facing the canopy end were reduced by up to $25 \mathrm{~cm}$. Fifteen days after pruning, hydrogen cyanamide (HC) (Dormex ${ }^{\circledR}, 49 \%$ HC, SKW, Trostberg, Germany) was applied at $0.5 \%$.

The plot was composed of two plants in which eight branches were marked, totaling 16 branches per cultivar. For the evaluations were selected branches of the previous year measuring, on average, between 10 and 35 $\mathrm{cm}$. Fifteen days after pruning, evaluations began. During the first stage, the count of buds per branch, number of shoots per branch, and number of brindles (floriferous branches) per marked branch was performed.

Aiming to identify superior cultivars with important characteristics for quince breeding, the number of fruit, estimated yield (measured in kilograms per hectare), flowering period (measured in days), number of buds, number of shoots, number of brindles per shoot, shoot length (measured in centimeter), average fruit weight (measured in grams), fruit length (measured in millimeters), and fruit diameter (measured in millimeters) were evaluated. Phenology-related characteristics were measured monthly, beginning at shoot emergence after pruning in June 2013. Shoot growth was monitored by measuring the length and number of existing nodes and shoot diameter at the end of production.

The production evaluation was performed by counting the total number of fruit per plant, resulting in the number of fruit produced throughout the quince production season. Plant yield was determined by multiplying the total number of harvested fruit by the total weight of the fruit from each harvest, and the estimated yield was calculated by multiplying the production value per plant by the density of plants per hectare (1.000 plants). Ten fruit were selected randomly per cultivar, and their length, diameter, and average weight were measured.

Gower distance and principal component analysis (PCA) were used to quantify the genetic diversity among cultivars. Fruit production, phenology and physical characteristics

Fig. 1. Dendrogram of genetic dissimilarity among quince cultivars based on a Gower distance matrix and unweighted pair group method with arithmetic means clustering.

Table 1. Principal component (PC) analysis showing the eigenvalues, proportions, and cumulative proportions of the quantitative traits from different quince cultivars in the tropics.

\begin{tabular}{|c|c|c|c|c|c|c|c|}
\hline Variables & PC 1 & PC 2 & PC 3 & PC 4 & PC 5 & PC 6 & PC 7 \\
\hline No. of fruit & 0.359 & 0.191 & 0.432 & -0.382 & 0.249 & 0.118 & 0.118 \\
\hline Estimated productivity $\left(\mathrm{kg} \cdot \mathrm{ha}^{-1}\right)$ & 0.438 & -0.036 & 0.265 & -0.348 & 0.279 & 0.024 & -0.005 \\
\hline Flowering duration (d) & 0.038 & -0.210 & 0.701 & 0.397 & -0.244 & -0.480 & 0.005 \\
\hline No. of buds & 0.316 & 0.401 & -0.135 & 0.092 & -0.130 & -0.377 & -0.341 \\
\hline No. of shoots & 0.259 & 0.345 & 0.062 & -0.020 & -0.767 & 0.378 & 0.193 \\
\hline No. of brindles & 0.201 & 0.316 & 0.056 & 0.731 & 0.415 & 0.371 & 0.054 \\
\hline Shoot length $(\mathrm{cm})$ & 0.390 & 0.174 & -0.365 & 0.010 & 0.045 & -0.427 & -0.149 \\
\hline Average fruit weight $(\mathrm{g})$ & 0.302 & -0.468 & -0.141 & 0.076 & -0.070 & 0.137 & -0.274 \\
\hline Fruit length (mm) & 0.357 & -0.318 & -0.272 & 0.128 & -0.009 & -0.177 & 0.761 \\
\hline Fruit diameter (mm) & 0.317 & -0.434 & -0.001 & 0.098 & -0.123 & 0.317 & -0.393 \\
\hline Eigenvector & 3.95 & 2.61 & 1.23 & 0.76 & 0.57 & 0.53 & 0.18 \\
\hline Total variation $(\%)$ & 39.53 & 26.06 & 12.25 & 7.56 & 5.65 & 5.32 & 1.83 \\
\hline Accumulated total variation $(\%)$ & 39.53 & 65.59 & 77.84 & 85.40 & 91.05 & 96.37 & 98.20 \\
\hline
\end{tabular}


were used for these analyses. Cruz et al. (2004) recommend the use of multivariate evaluations of cultivars from germplasm banks because replicates are not always available, making it difficult to quantify the environmental influences on individuals. Based on a dissimilarity matrix $(27 \times 27)$, the agglomerative clustering method of the average linkage among groups (UPGMA) was applied to establish groups of cultivars. The efficiency of the hierarchical clustering method was tested based on cophenetic correlation coefficients (CCCs) estimated according to the methodology described by Sokal and Rohlf (1962). The cutoff point of the dendrogram formed by the UPGMA method was defined according to Mojena (1977).

The identification of superior genotypes from the simultaneous selection of the 10 evaluated traits was performed based on the rank summation index and the index of the sum of the standardized variables, or Z-

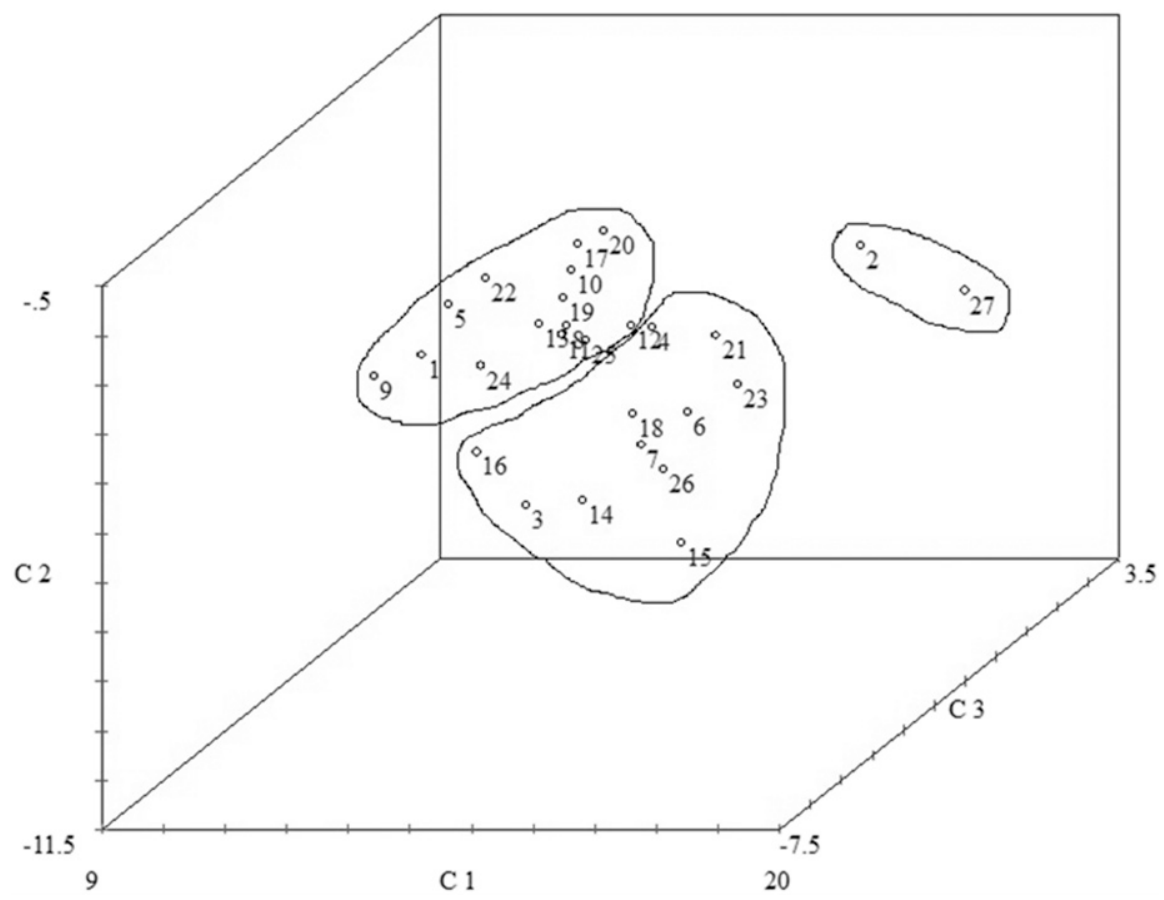

Fig. 2. Dispersion graph obtained through evaluated principal components based on 10 agronomic traits in 27 quince cultivars. (1) 'Zuquerineta'; (2) 'Alaranjado'; (3) 'Van Deman'; (4) 'Fuller'; (5) 'De Vranja'; (6) 'Lajeado'; (7) 'Radaelli'; (8) 'Reas Mamouth'; (9) 'Champion'; (10) 'Cheldow'; (11) 'Portugal'; (12) 'CTS'; (13) 'Provence'; (14) 'Pineapple'; (15) 'Mendoza Inta-37'; (16) 'Constantinopla'; (17) 'Dangers'; (18) 'Dulot'; (19) ‘Apple'; (20) ‘De Patras'; (21) ‘Alongado'; (22) 'Pera'; (23) 'Meliforme'; (24) 'Smyrna'; (25) 'Kiakami'; (26) 'Meech Prolific'; and (27) 'Bereckzy'. in repetition $j$; and $S j k$ is the phenotypic SD of characteristic $k$ in repetition $j$. Because the variable $Z$ can assume both negative and positive values, the number three was added to the values to make them positive. In this case, the population average, instead of zero, assumed the value three. After standardization of the variables, the sum of the Z-values was obtained: $\Sigma Z i j k=Z i j 1+Z i j 2+\ldots+Z i j n$. To verify the similarities of the selections identified through each index, the coincidence percentage of the selection was estimated.

Multivariate analyses were performed using Genes software (Cruz, 2013), and Excel software was used for the rank summation index and to obtain the Z-index.

\section{Results and Discussion}

The clustering analysis based on Gower distance and clusters by UPGMA had a CCC of 0.80 and formed three groups (Fig. 1), using the cutoff line suggested by Mojena (1977). The maximum distance (dii') was obtained between cultivars Bereckzy and Champion $\left(\mathrm{dii}^{\prime}=0.69\right)$; the minimum distance was between cultivars Dulot and Radaelli (dii' $=0.07)$. The maximum genetic distance indicates the most divergent cultivars; the minimum distance, the most similar cultivars. Cultivars Bereckzy and Champion were more divergent than other cultivar pairs as a result of their large differences in number of fruit, yield, flowering duration, numbers of buds and brindles, shoot length, and fruit weight. However, cultivars Dulot and Radaelli were more similar than other cultivar pairs because their evaluated characteristics were very similar.

Group 1 was composed of cultivars Alaranjado and Bereckzy, accounting for $7.4 \%$ of the total quince cultivars. This group, on average, had predominately the greatest values for all analyzed characteristics, except for flowering days and fruit weight. Group 2 $(40.7 \%)$ was formed by cultivars Dulot, Radaelli, Meliforme, Pineapple, Van Deman, Mendoza Inta-37, Constantinopla, Meech Prolific, Lajeado, Alongado, and Fuller. This group was characterized by having heavier fruit $(223.3 \mathrm{~g})$ and a longer flowering period (46.7 d) than cultivars in other groups. Group III $(51.9 \%)$ consisted of cultivars Champion, Zuquerineta, De Vranja, Kiakami, Smyrna, Apple, Pera, CTS, De Patras, Dangers,

Table 2. Matrix of the phenotypic correlation among the quantitative traits from different quince cultivars in the tropics.

\begin{tabular}{|c|c|c|c|c|c|c|c|c|c|}
\hline Variables & NF & $\mathrm{Y}$ & $\mathrm{DF}$ & NB & NS & $\mathrm{BN}$ & $\mathrm{BL}$ & AFW & FD \\
\hline Estimated productivity $\left(\mathrm{kg} \cdot \mathrm{ha}^{-1}\right)$ & $0.86^{* *}$ & & & & & & & & \\
\hline $\mathrm{NB}$ & $0.50^{* *}$ & $0.41 *$ & -0.15 & & & & & & \\
\hline NS & $0.49 * *$ & 0.32 & -0.09 & $0.63 * *$ & & & & & \\
\hline $\mathrm{SL}(\mathrm{cm})$ & 0.42 & $0.53 * *$ & -0.23 & $0.76 * *$ & $0.42 * *$ & 0.36 & & & \\
\hline AFW (g) & 0.08 & $0.49 * *$ & 0.17 & -0.08 & -0.07 & -0.10 & 0.28 & & \\
\hline FL (mm) & 0.17 & $0.51 * *$ & 0.07 & 0.17 & 0.04 & 0.04 & $0.52 * *$ & $0.81 * *$ & \\
\hline
\end{tabular}

*** Significant at $1 \%$ and $5 \%$ probability by $t$ test, respectively.

$\mathrm{NF}=$ number of fruit; $\mathrm{Y}=$ estimated yield; $\mathrm{DF}=$ duration of flowering; $\mathrm{NB}=$ number of buds; $\mathrm{NS}=$ number of shoots; $\mathrm{BN}=$ brindle number; $\mathrm{SL}=$ shoot length; $\mathrm{AFW}=$ average fruit weight; $\mathrm{FD}=$ fruit diameter. 
Table 3. Classification based on the rank summation index of 27 quince cultivars in the tropics in relation to 10 agronomic and phenologic traits.

\begin{tabular}{|c|c|c|c|c|c|c|c|c|c|c|c|}
\hline \multirow[b]{2}{*}{ Cultivars } & \multicolumn{10}{|c|}{ Agronomic and phenologic traits } & \multirow{2}{*}{$\begin{array}{c}\text { Rank summation } \\
\text { index }\end{array}$} \\
\hline & $\mathrm{NF}$ & $\mathrm{Y}$ & DF & NB & NS & $\mathrm{BN}$ & $\mathrm{SL}$ & AFW & FD & FL & \\
\hline Bereckzy & 1 & 1 & 11 & 1 & 2 & 2 & 2 & 4 & 4 & 2 & 30 \\
\hline Alaranjado & 2 & 1 & 17 & 2 & 3 & 3 & 4 & 14 & 8 & 14 & 68 \\
\hline Meliforme & 3 & 2 & 4 & 20 & 8 & 10 & 21 & 9 & 3 & 8 & 88 \\
\hline Alongado & 4 & 4 & 13 & 5 & 6 & 9 & 1 & 12 & 9 & 10 & 73 \\
\hline Fuller & 5 & 6 & 18 & 3 & 4 & 15 & 7 & 13 & 14 & 15 & 100 \\
\hline De Patras & 6 & 7 & 5 & 11 & 7 & 9 & 11 & 26 & 23 & 26 & 131 \\
\hline Kiakami & 7 & 9 & 1 & 25 & 15 & 14 & 26 & 19 & 21 & 16 & 153 \\
\hline Cheldow & 8 & 14 & 21 & 12 & 5 & 4 & 20 & 21 & 22 & 20 & 147 \\
\hline Apple & 9 & 15 & 9 & 22 & 1 & 17 & 24 & 17 & 27 & 12 & 153 \\
\hline Reas Mamouth & 10 & 20 & 14 & 13 & 12 & 6 & 5 & 18 & 15 & 21 & 134 \\
\hline Van Deman & 11 & 13 & 16 & 27 & 15 & 16 & 27 & 5 & 12 & 5 & 147 \\
\hline Dangers & 12 & 22 & 6 & 7 & 2 & 6 & 16 & 24 & 24 & 23 & 142 \\
\hline Dulot & 13 & 12 & 7 & 9 & 13 & 11 & 13 & 6 & 11 & 9 & 104 \\
\hline Radaelli & 14 & 8 & 3 & 18 & 12 & 14 & 15 & 8 & 5 & 7 & 104 \\
\hline Portugal & 15 & 17 & 12 & 10 & 10 & 8 & 10 & 16 & 16 & 19 & 133 \\
\hline Pera & 16 & 23 & 26 & 4 & 2 & 18 & 8 & 28 & 17 & 27 & 169 \\
\hline Meech Prolific & 17 & 3 & 20 & 17 & 11 & 10 & 3 & 2 & 7 & 4 & 94 \\
\hline Provence & 18 & 18 & 23 & 8 & 9 & 4 & 19 & 15 & 18 & 17 & 149 \\
\hline Lajeado & 19 & 10 & 15 & 6 & 4 & 5 & 6 & 7 & 2 & 6 & 80 \\
\hline Zuquerineta & 20 & 19 & 19 & 23 & 18 & 13 & 25 & 23 & 26 & 22 & 208 \\
\hline Mendoza Inta-37 & 21 & 5 & 8 & 16 & 14 & 19 & 9 & 1 & 1 & 1 & 95 \\
\hline Pineapple & 22 & 11 & 10 & 24 & 15 & 16 & 18 & 3 & 10 & 3 & 132 \\
\hline De Vranja & 23 & 16 & 22 & 15 & 16 & 7 & 17 & 27 & 25 & 24 & 192 \\
\hline CTS 207 & 24 & 21 & 5 & 14 & 5 & 1 & 14 & 10 & 13 & 11 & 118 \\
\hline Smyrna & 25 & 24 & 2 & 19 & 18 & 12 & 23 & 22 & 20 & 18 & 183 \\
\hline Champion & 26 & 26 & 24 & 26 & 17 & 14 & 22 & 25 & 19 & 25 & 224 \\
\hline Constantinopla & 27 & 25 & 25 & 21 & 11 & 12 & 12 & 11 & 6 & 13 & 163 \\
\hline
\end{tabular}

$\mathrm{NF}=$ number of fruit; $\mathrm{Y}=$ estimated yield; $\mathrm{DF}=$ duration of flowering; $\mathrm{NB}=$ number of buds; $\mathrm{NS}=$ number of shoots; $\mathrm{BN}=$ brindle number; $\mathrm{SL}=$ shoot length; $\mathrm{AFW}=$ average fruit weight; $\mathrm{FD}=$ fruit diameter.

Provence, Cheldow, Portugal, and Reas Mamouth. This group was the most diverse and isolated, and it showed the least values for all evaluated characteristics, except for the number of fruit per plant (Fig. 1).

Similar results with high genetic variability were observed by Bassil et al., (2011) when simple sequence repeat markers were used to determine the genetic variability among 92 quince genotypes and three intergeneric pear $\times$ hybrid quinces $[\times$ Pyronia veitchii (Trab.) Guillaumin]. Kafkas et al. (2015) also showed the presence of genetic variability when 40 quince accessions from Turkey were characterized using amplified fragment length polymorphism markers. Yuksel et al. (2013) performed molecular analyses in 15 traditional quince cultivars and found a similar relationship between $18 \%$ and $87 \%$ among cultivars.

In the dispersion analysis, the first three components explained $77.8 \%$ of the total accumulated variance. The first component (PC1) accounted for $39.53 \%$; the second (PC2), 26.06\%; and third (PC3), 12.25\% (Table 1). The characteristics that contribute most to the components are those with greater eigenvalues in the main components. In contrast, the lower contributions are from those with greater eigenvectors in fewer components (Cruz et al., 2004).

Table 1 shows that the first $\mathrm{PC}$ axis was correlated mainly with yield $(0.438)$ and shoot length (0.390), with $39.53 \%$ of the total variation. The second $\mathrm{PC}$ axis, with $26.06 \%$ of the total variation, correlated strongly with fruit weight and diameter $(0.468$ and 0.434 , respectively). The flowering period $(0.701)$ correlated strongly with the third axis of the
PC, which represented $12.25 \%$ of the total variation. According to Mamede et al. (2013), the more attributes closer to a larger axis, the more the sample explains the variability among samples, which justifies the greater percentage for $\mathrm{PC} 1$ than for the other PCs.

The results presented in Figs. 1 and 2 show the similarities in the distribution of the formed groups according to the cultivars shown in the dendrogram and through graphical analysis using the PCs. According to Cruz et al. (2004), UPGMA clustering allows more similar cultivars within groups to be identified than other multivariate methods.

Despite the diversity found among quince cultivars, only superior cultivars are significant in relation to the most important characteristics and mainly have high yields. The diversity results indicate the genetic variability between the formed groups, and this information can contribute to and guide future research strategies. The use of this variability may occur through the selection of cultivars from groups 1 and 2, with greater averages for the main agronomic and phenologic characteristics of interest, such as number of fruit, estimated yield, duration of flowering, number of buds, number of shoots, number of brindles per shoot, shoot length, average weight of fruit, and length and diameter of the fruit.

Based on the results of the PCs, it was possible to obtain a Pearson correlation coefficient matrix for the 10 characteristics (Table 2). A high-magnitude and significant correlation was observed among several characteristics, and this parameter suggests the possibility of achieving gains with the indirect selection of one variable in relation to another (Greco et al., 2014). Fruit weight exceled by showing a positive correlation with a high magnitude with fruit diameter $(r=$ $0.94)$ and fruit length $(r=0.81)$. Yield was highly correlated with the number of fruit $(r=$ 0.86 ). These correlations were already expected, because they indicate that cultivars with greater fruit weight tend to have larger fruit and therefore greater yields. The correlation between the number of buds and shoot length $(r=0.76)$ was significant and of high magnitude. Silva et al. (2013) also found high positive correlations between the diameter and length of peach fruit. This strong correlation indicates that environmental factors, such as the nutritional regime, may play a significant role in fruit size and quality. Thus, for the indirect selection of quince cultivars with good shoot development, it is necessary to select cultivars with high physical fruit characteristics, thus obtaining greater yields.

With the aim of identifying the most divergent cultivars that also have the greatest averages in relation to the selection traits, a ranking of variables considered important in quince crops was performed, enabling the selection of superior cultivars. The results of the ranking are presented in Table 3. According to the criteria established for the characteristics, the rank summation index varied from 30 to 224 for the cultivars Bereckzy and Champion. A lesser value indicates a more favorable combination among all selection traits. Thus, based on the rank summation index, it was verified that Bereckzy, Alaranjado, and Alongado are promising for crop expansion in relation to other cultivars. It is 

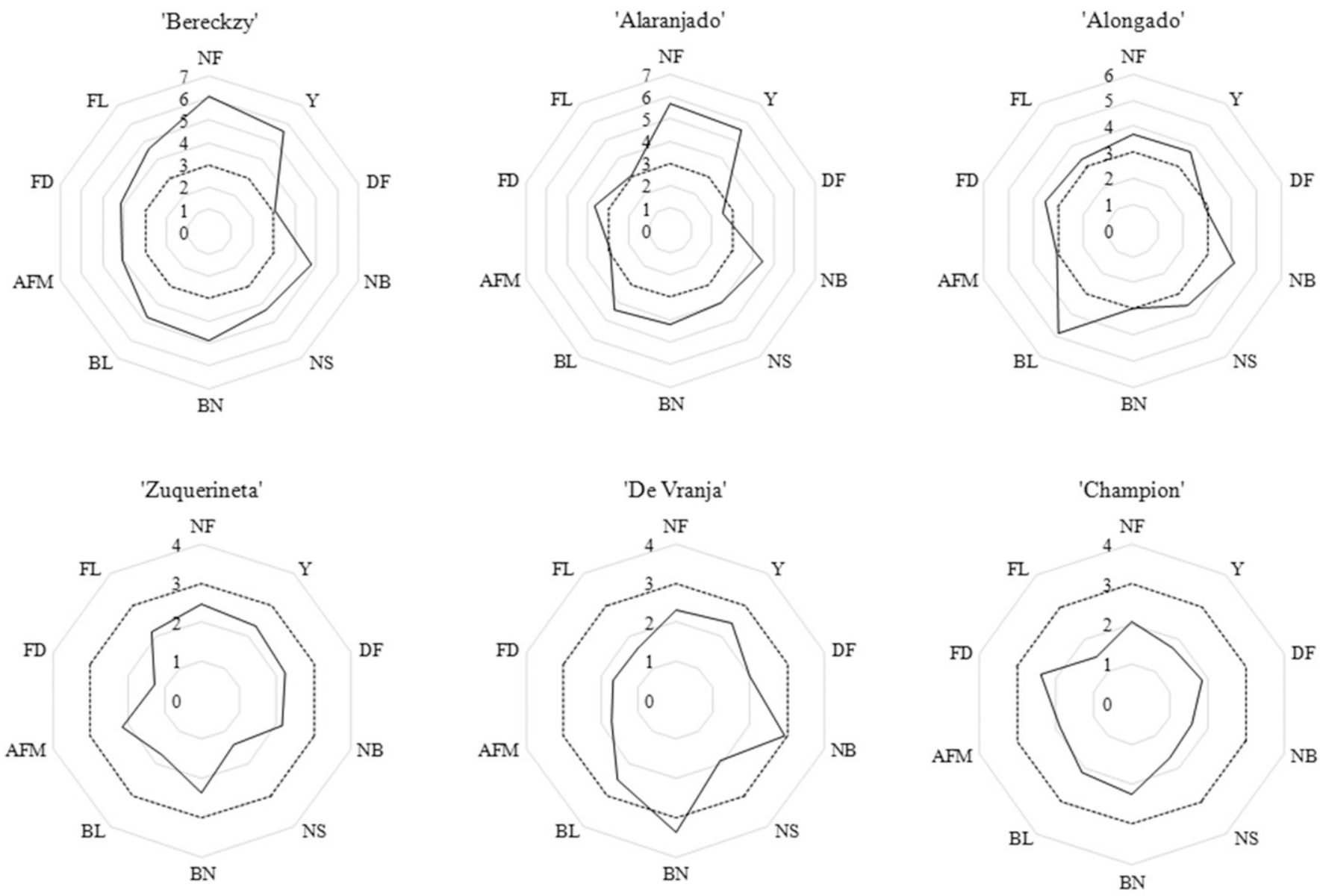

Standardized values

Average overall $(\mathrm{n}=3)$

Fig. 3. Graphical representation of the standardized values (Zij) of 10 agronomic and phenologic traits of cultivars with the highest and lowest Z-index values. NF, number of fruit; Y, estimated yield; DF, duration of flowering; NB, number of buds; NS, number of shoots; BN, brindle number; SL, shoot length; AFW, average fruit weight; $\mathrm{FD}$, fruit diameter.

expected that these cultivars form populations with a high probability of obtaining clones with high potentials for agronomic characteristics.

In the comparison between Z-indexes and rank summation index, $100 \%$ coincidence was verified among the selected quince cultivars. According to Vieira et al. (2017), the greater the coincidence coefficient between two selection indices, the greater the similarity of the selection results between them.

Figure 3 shows the graphs of the cultivars that had the best and the worst performance, on average, for the 10 evaluated traits according to the Z-index. It is noteworthy that 'Bereckzy', 'Alaranjado', and 'Alongado' had a greater or similar performance than that calculated by the average of the 10 evaluated traits; hence, they were identified as having the best performance. This result demonstrates the possibilities of quince diversification with the selected cultivars. Cultivars Zuquerineta, De Vranja, and Champion had lower than average performance and the lowest performance among the 27 evaluated for all traits.
Studying the genetic diversity associated with the use of selection index techniques for quince cultivars is an important step in the processes of breeding and selecting cultivars, because it allows individuals with superior characteristics to be identified in a timesaving manner. Furthermore, studying genetic diversity provides practical guidelines for future studies aiming to revitalize national quince crop production by obtaining more promising cultivars in traditional crop areas.

\section{Conclusions}

The UPGMA groups indicated there was genetic variability among cultivars and showed that groups with more dissimilar cultivars had the potential to be used in future stages of quince selection. In our study, it was shown that productivity parameters, including shoot length, fruit weight and diameter, and flowering period, contributed to the maximum variability among quince cultivars. Regarding the simultaneous evaluation of all traits, the use of selection indices allowed the superior cultivars Bereckzy, Alaranjado, and Alongado to be identified.

\section{Literature Cited}

Alp, S., S. Ercisli, H. Dogan, E. Temim, A. Leto, M. Zia-Ul-Haq, A. Hadziabulic, and H. Aladag. 2016. Chemical composition and antioxidant activity Ziziphora clinopodioides ecotypes from Turkey. Rom. Biotechnol. Lett. 21:11298-11303.

Alvares, C.A., J.L. Stape, P.C. Sentelhas, J.L.M. Gonçalves, and G. Sparovek. 2013. Köppen's climate classification map for Brazil. Meteorol. Zeitschrift 22:711-728.

Barbosa, W., E.A. Chagas, C.V. Pommer, and R. Pio. 2010. Advances in low-chilling peach breeding at Instituto Agronômico, São Paulo State, Brazil. Acta Hort. 872:147-150.

Bassil, N.V., J.D. Postman, K.E. Hummer, J. Mota, D. Sugar, and R. Williams. 2011. Quince (Cydonia oblonga) genetic relationships determined using microsatellite markers. Acta Hort. 909:75-84.

Bertini, C.H.C.M., W.S. Almeida, A.P.M. Silva, J.W.L. Silva, and E.M. Teófilo. 2010. Multivariate analysis and selection index for identification of cowpea genotypes. Acta Sci. Agron. 32:613-619.

Bettiol Neto, J.E., R. Pio, J. Sanches, E.A. Chagas, P. Cia, and P.C. Chagas. 2011. Production and quality attributes of quince tree cultivars in the eastern of the state of São Paulo. Rev. Bras. Frutic. 33:1035-1042. 
Chagas, E.A., P.C. Chagas, R. Pio, J.E. Bettiol Neto, J. Sanches, S.A. Carmo, P. Cia, M. Pasqual, and A.S. Carvalho. 2012. Production and quality attributes of apple tree cultivars in subtropical conditions at eastern of São Paulo state. Cienc. Rural 42:1764-1769.

Cruz, C.D. 2013. Genes: A software package for analysis in experimental statistics and quantitative genetics. Acta Sci. Agron. 35:271276.

Cruz, C.D., A. Regazzi, and P.C.S. Carneiro. 2004. Modelos biométricos aplicados ao melhoramento genético. $3^{\circ}$ edição. Viçosa: Editora UFV, v.1. 480 p.

Dall'Orto, F.A.C., M. Ojima, R. Pio, and E.A. Chagas. 2007. Evaluation of reproductive capacities from some quinces cultivate of seeking for rootstocks. Cienc. Agrotec. 31:274-278.

Dogan, H., S. Ercisli, E. Temim, A. Hadziabulic, M. Tosun, S.O. Yilmaz, and M. Zia-Ul-Haq. 2014. Diversity of chemical content and biological activity in flower buds of a wide number of wild grown caper (Capparis ovate Desf.) genotypes from Turkey. CR Acad. Bulg. Sci. 67:1593-1600.

Ercisli, S., A. Esitken, R. Cangi, and F. Sahin. 2003. Adventitious root formation of kiwifruit in relation to sampling date, IBA and Agrobacterium rubi inoculation. Plant Growth Regulat. 41:133-137.

FAO. 2017. FAOSTAT database. 28 June 2017. $<$ http://faostat.fao.org/>.

Fattouch, S., P. Caboni, V. Coroneo, C.I.G Tuberoso, A. Angioni, S. Dessi, N. Marzouki, and P. Cabras. 2007. Antimicrobial activity of Tunisian quince (Cydonia oblonga Miller) pulp and peel polyphenolic extracts. J. Agr. Food Chem. 55:963-969.

França, A.E.D., R.A.C. Parrella, V.F. Souza, G.Q. Bastos, J.A.R. Nunes, and R.E. Schaffert. 2016. Simultaneous selection in sweet sorghum progenies by selection indices. Pesqui. Agropecu. Bras. 51:1737-1743.
Greco, S.M.L., J.R. Peixoto, and L.M. Ferreira. 2014. Physical assessment, and physical chemistry and estimates of genetic parameters 32 genotypes passionfruit sour cultivated in federal district. Biosci. J. 30:360-370.

Hamauzu, Y., T. Inno, C. Kume, M. Irie, and K. Hiramatsu. 2006. Antioxidant and antiulcerative properties of phenolics from Chinese quince, quince, and apple fruits. J. Agr. Food Chem. 54:765-772.

IBGE. 2017. Sistema IBGE de recuperação automática: Sidra. Produção agrícola municipal: Produção de marmelo. 13 June 2017. $<$ http://www.sidra.ibge.gov.br/>.

Kafkas, S., H. Topcu, A. Dogan, M.E. Akcay, and S. Ercisli. 2015. Genetic relatedness among quince (Cydonia oblonga Miller) accessions from Turkey using amplified fragment length polymorphisms. J. Appl. Bot. Food Qual. 88(1):197-201.

Leonel, M., S. Leonel, M.A. Tecchio, M.F. Moura, and D. Xavier. 2016. Characteristics of quince fruits cultivars' (Cydonia oblonga Mill.) grown in Brazil. Austral. J. Crop Sci. 10:711-716.

Mamede, M.E.O., M. Suzarth, M.A.C.L. Jesus, J.F.M. Cruz, and L.C. Oliveira. 2013. Avaliação sensorial e colorimétrica de néctar de uva. Brazilian J. Food Nutr. 24:65-72.

Manica-Berto, R., C. Pegoraro, C.C. Mistura, A.P.S. Bresolin, A.R. Rufato, and J.C. Fachinello. 2013. Genetic similarity between quince cultivars evaluated by AFLP markers. Pesqui. Agropecu. Bras. 48:568-571.

Mojena, R. 1977. Hierarchical grouping methods and stopping rules: An evaluation. Comput. J. 20:359-363.

Mulamba, N.N. and J.J. Mock. 1978. Improvement of yield potential of the 'Eto Blanco' maize (Zea mays L.) population by breeding for plant traits. Egypt. J. Genet. Cytol. 7:40-57.

Orhan, E., G. Agar, and S. Ercisli. 2014. Genetic variation among quince (Cydonia oblonga Mill.) genotypes sampled from the Coruh valley in Turkey. Genet. Mol. Res. 13:445-449.

Rigitano, O. 1957. O marmeleiro e sua cultura. Melhoramento, São Paulo, Brasil.

Seifert, K.E., R. Pio, V.M. Celant, and E.A. Chagas. 2009. Pear seedling production by double grafting in quince using 'Japonês' as rootstock. Pesqui. Agropecu. Bras. 44:16311635.

Silva, B.M., P.B. Andrade, P. Valentao, F. Ferreres, R.M. Seabra, and M.A. Ferreira. 2004. Quince (Cydonia oblonga Miller) fruit (pulp, peel, and seed) and jam: Antioxidant activity. J. Agr. Food Chem. 52:4705-4712.

Silva, D.F.P., J.O.C. Silva, R.G.P. Matias, M.A.R Ribeiro, and C.H. Bruckner. 2013. Correlation between quantitative and qualitative characteristics of fruits of peach trees grown in subtropical conditions. Rev. Ceres 60:53-58.

Sokal, R.R. and F.J. Rohlf. 1962. The comparison of dendrograms by objective methods. Taxon $11: 33-40$.

Souza, F.B.M., A.A. Alvarenga, R. Pio, E.D. Gonçalves, and L.S. Patto. 2013. Fruit production and quality of selections and cultivars of peach trees in Serra da Mantiqueira, Brazil. Bragantia 72:133-139.

Teixeira, D.H.L., M.S.P. Oliveira, F.M.A. Gonçalves, and J.A.R. Nunes. 2012. Selection index for simultaneously improving fruit production components of assai palm. Pesqui. Agropecu. Bras. 47:237-243.

Vieira, S.D., D.C. Souza, I.A. Martins, G.H.M.R. Ribeiro, L.V. Resende, A.K.L. Ferraz, A.G. Galvão, and J.T.V. Resende. 2017. Selection of experimental strawberry (Fragaria $\times$ ananassa) hybrids based on selection indices. Genet. Mol. Res. 16(1):1-11.

Yuksel, C., F. Mutaf, I. Demirtas, G. Ozturk, M. Pektas, and A. Ergul. 2013. Characterization of Anatolian traditional quince cultivars, based on microsatellite markers. Genet. Mol. Res. 12: 5880-5888. 